\title{
13 International Policy Opportunities for True Cost Accounting in Food and Agriculture
}

\author{
Barbara Gemmill-Herren, Zoltán Kálmán and \\ Alexander Müller
}

\section{Why the International Level?}

Food and agriculture policy might often be seen as being formulated, adopted, and implemented on the level of the nation state. But national policies in turn are embedded within a set of international agreements ranging from World Trade Organization (WTO) rules to those regional bodies seeking to harmonize agricultural policies throughout a continent such as the European Union in Europe and Mercosur in Latin America. There are a number of compelling reasons for considering international entry points for the True Cost Accounting (TCA) for externalities in food and agriculture. In at least three respects (at a minimum) the international agenda is pivotal to the adoption of TCA in the food and agriculture sector: 1) addressing the seemingly intractable paradigm of "feeding the world" and its implicit coda, "with cheap food"; 2) facing the reality that - through international trade - the burden of externalities is so readily shifted across borders and continents, often from the Global North to the Global South; and 3) recognizing that externalities of the food system have impacts on many levels, from local to global.

\section{Feeding the World with Cheap Food}

With great regularity, alarms have been set off as to how the world will feed a growing population, using a common reference point of the year 2050. Also, almost uniformly, the question is met with estimates of how much food production needs to be increased. Estimates have varied from a need to double food production (often repeated but not actually backed up by analysis), to a $70 \%$ increase (Food and Agriculture Organization of the United Nation, 2009), and then a $60 \%$ recalculation (Alexandratos and Bruinsma, 2012). Nonetheless, the need for vast increases in food production has been the dominant narrative that continues to find its way into the popular media ${ }^{1}$ and drives the productionist agendas of international agricultural research, development aid, and philanthropy (Wise, 2020; Pimbert and Moeller, 2018; Biovision and IPES-Food, 2020). This reference point and narrative is the rationale behind government support for highinput intensive industrial farming and farm consolidation, in developed and developing countries alike. 
The weaknesses in these estimates and their underlying models have been enumerated by many scholars; including:

- The fact that the root causes of hunger-extreme poverty and gaping inequalities - persist stand as a damning indictment of the global food system. However, several estimates indicate that enough food is produced today to feed from 9 billion (IPES-Food, 2016; High Level Panel of Experts on Food Security and Nutrition, 2014, 2017; Chappell, 2018) to almost 10 billion people (Berners-Lee et al., 2018). At the same time, around one-third of this is lost or wasted (High Level Panel of Experts on Food Security and Nutrition, 2014). Access, equity, distribution, and addressing food waste remain key problems.

- Global business models that bank on the expectation that over the next 30 years, the global community will adopt Western, grain-fed meat-centered diets, despite growing environmental and health concerns. This leads to policy and practice that continues to divert food grains to livestock feed and biofuel production, despite considerable criticism of biofuel policy (Wise, 2013). Nor is food loss and waste being reduced to the greatest extent possible (High Level Panel of Experts on Food Security and Nutrition, 2014), and as committed to within the Sustainable Development Goals ("By 2030, halve per capita global food waste at the retail and consumer levels and reduce food losses along production and supply chains, including post-harvest losses"). Berners-Lee et al. (2018) make intricate global quantifications of the extent to which reductions in the amount of human-edible crops fed to animals and, less importantly, reductions in waste, could increase food supply. They find that no nutritional case can be made for feeding human-edible crops to animals, which reduces calorie and protein supplies for global food security.

- The assumption that food and nutritional security can be resolved through increased production, "intensification" and technical change, when hunger and malnutrition has been thoroughly documented to be first and foremost an issue of different entitlements (Sen, 1981; Smith and Haddad, 2015; High Level Panel of Experts on Food Security and Nutrition, 2017). Smith and Haddad (2015), for instance, reviewed studies to address child malnutrition carried out over a 42-year period, from 1970 to 2012, spanning 116 countries. They found that the predominant and strongest contributors to reducing hunger were not related to agricultural production but were social measures and issues of entitlement: access to safe water and female education (Figure 13.1). Contributors related to production figure next, although access to dietary energy from non-staples (thus, primarily legumes, fruits, and vegetables) are almost as important as dietary energy from staples (rice, maize, wheat, root crops, etc.). Two of the other predominant determinants to reducing child nutrition are also social measures: access to sanitation and the ratio of female to male life expectancy. 


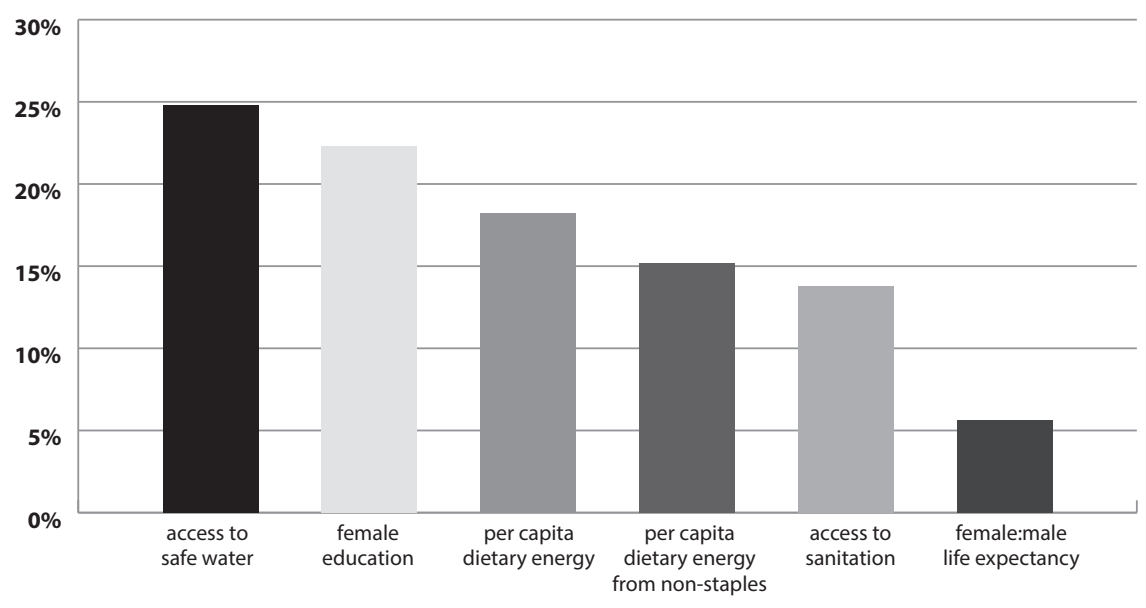

Figure 13.1 Contributions of underlying determinants to reducing hunger.

Source: adapted from Smith \& Haddad, 2015.

- Inadequate attention in policy and practice to nutrition and equitable prices for food. The most recent "State of World Food Security and Nutrition in the World" finds that hunger has increased globally since 2015. This same report finally considered healthy diets to be integral to food security, not just limited to the consumption of staples. The authors also explored the fact that costs of healthy diets at current prices are $60 \%$ higher than the cost of a diet that might not be healthy, but does provide adequate nutrition, and five times the cost of an energy sufficient diet. While most of the poor around the world can afford an energy-sufficient diet, as defined in the report, they cannot afford either a nutrient-adequate or a healthy diet (Food and Agriculture Organization of the United Nations et al., 2020). As the report notes, "the unaffordability of healthy diets is due to their high costs relative to people's incomes, a problem likely to be exacerbated by COVID-19". As observed by the new Special Rapporteur on the Right to Food, Michael Fakhri, government policies always directly or indirectly influence food prices, and the overwhelming trend has been to drive down food prices for merely energy efficient (calories only) diets (Fakhri and Tzouvala, 2020). Countries need guidance to genuinely address hunger, nutrition, and healthy diets. Cheap food currently replaces social safety nets, although inadequately; the paradigm of cheap food is responsible for poor and often hungry famers and causes high health risks for poor people. The recognition of nutritious food as a human right, together with incomes to sustain healthy diets among farming communities and food chain workers, would ensure food and nutrition security as envisioned in the United Nations' Sustainable Development Goals.

- The inherent inaccuracy of predictions of world food production, most often based on global estimates of supply and demand, yet, as eloquently phrased by Wise (2013): 
“.... ecosystems and agricultural production occur at local and regional scales. So too does hunger. Thus, global estimates of "our" ability to feed "the world" immediately break down, begging the more important questions of how these systems develop across widely differing landscapes, societies, and levels of economic development, and how equitably the food is then distributed. In the end, "the world" is not fed, in aggregate, and there is no collective "we" doing the feeding."

There is no question that yield potential varies considerably by crop and region, and that many agricultural lands with significant yield gaps are in rainfed zones in developing countries. However, the specific pathways for increasing such production must recognize that food and farming systems are complex socio-ecological systems, each with distinct needs to be addressed in terms of resources, power imbalances, and ecological constraints. Here again, governments can learn from each other and benefit from guidance in navigating such complex landscapes, rather than implementing programs based on the belief that technological fixes to production are the solution. The ongoing discussions of the Committee on World Food Security's (CFS) Voluntary Guidelines on Food Systems and Nutrition (based on the related High Level Panel of Experts on Food Security and Nutrition [HLPE] Report) will also provide appropriate guidance in this regard.

\section{International Trade}

The global food system is, in the words of The Economist, "the unsung star of $21^{\text {st }}$ century logistics," making up an $\$ 8$ trillion global supply chain that accounts for about a tenth of global Gross Domestic Product (GDP) (The Economist, 2020) and employing one out of every three economically active workers (Food and Agriculture Organization of the United Nations, 2014). Although farming is inherently local, the food industry is increasingly global. Food exports have grown sixfold over the past 30 years. The companies that dominate this trade operate on a global basis to source and ship agricultural commodities to food processing facilities and then to consumers. As The Economist notes, their size and global reach permit them to generate substantial profits on narrow margins, by quickly swapping one source or one market for another to accommodate changes in supply or demand (The Economist, 2020).

At the same time, this global food system is responsible for widespread degradation of land, water, and ecosystems; high greenhouse gas emissions; biodiversity losses; chronic over- and undernutrition and diet-related diseases; and livelihood stresses for farmers (Pengue et al., 2018).

Industrial, input-intensive food systems have been found globally responsible for $19 \%$ to $29 \%$ of greenhouse gas emissions (Andrieu and Kebede, 2020), 61\% of fish population decline (United Nations Environment Programme, 2016) and the use of $20 \%$ of aquifers (United Nations Environment Programme, 2016). Agriculture is the main driver of land degradation (Intergovernmental Panel on Climate Change, 2019). Estimated costs of inaction continue to 
mount; for example, it is estimated that the world lost between $\$ 6$ trillion and $\$ 11$ trillion in ecosystem services between 1997 and 2011, owing to land degradation (Organisation for Economic Co-operation and Development, 2019). Under current food consumption patterns, diet-related health costs are projected to reach $\$ 1.3$ trillion per year in 2030 , and diet-related social costs of greenhouse gas emissions associated with the current food system are projected to exceed \$1.7 trillion per year (Food and Agricultural Organisation of the United Nations et al., 2019)

An emerging feature of global food systems is the existence of multiple, insidious forms of visible and invisible flows of natural resources and externalities, across borders and continents. For each shipment of food being transported beyond national borders, the natural resources used in the production of such shipments are also, in a sense, being "virtually" transported to the recipient country. This was highlighted in Pengue et al. (2018), considering the growing quantities of trade in biomass, nutrients and "embedded" water over time. Overall, about 15 per cent of all biomass materials globally extracted are redistributed from one country to another through trade (www.materialflows.net/home; United Nations Environment Programme, 2015). As food and other products are traded internationally, water and nutrient resources in one country are used to support consumption in another country (Figure 13.2). Argentina, for example, as a large food and biomass supplier to the world, is equally a main extractor of water and nutrients, largely consumed in Asia (Pengue et al., 2018).
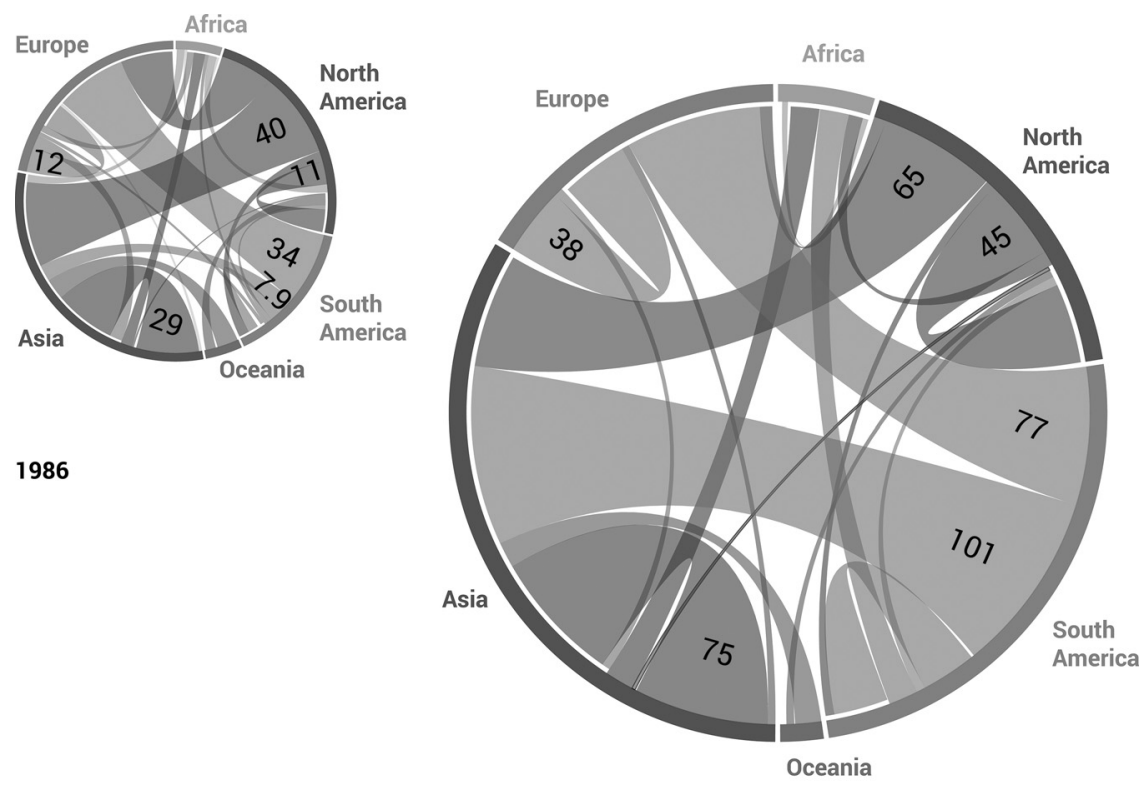

2007

Figure 13.2 Virtual water flows between the six world regions, 1986 and 2007.

Source: TEEB, 2018; adapted from Dalin et al. 2012. 
As an example of how local practices add up to major global trends, biogeochemical flows throughout the world have been profoundly transformed as farming systems have turned from traditional means of maintaining soil fertility (through fallowing, integrating livestock with crops, applying crop rotation, intercropping, cover crops, use of pulses and legumes, reduced tillage, and use of composted material) to the increased use of fossil-fuel-based and mined fertilizers. Agricultural intensification, carried out without restorative practices, ultimately leads to soils unable to sustain their fertility. To compensate, modern conventional farming enterprises have increased the use of NPK (nitrogen, phosphorus and potassium) fertilizers (Figure 13.3). Nitrogen and phosphorous both are notoriously "leaky" nutrients that end up in waterways when applied in excess. As an outcome of agriculture's increased biomass production, "cascades" of nitrogen and phosphorus are causing serious pollution of water bodies, leading to nitrate contamination of drinking water and "dead zones" in oceans and other water bodies (Lassaletta et al., 2016; Ribaudo et al., 2011; Cox and Schechinger, 2018; Townsend and Howarth, 2010).

Thus, accounting for negative externalities such as soil depletion, nutrient pollution, and overextraction of water along the value chain is a transboundary issue. Global trade leads to significant incomes for exporting countries, but TCA questions would be: Are the negative externalities accounted for? And do the export earnings contribute to restoring the natural resources that a country exports?

While globally traded foodstuffs, together with inputs such as pesticides and fertilizers flow fairly abundantly between borders, the human workforces that sustain agriculture and food systems are subject to a different dynamic. The labor force in agriculture and food systems is among the least valued of all sectors, in all countries of the world, with many areas of concern around the lack of protections for human rights. In the USA, for example, farmworkers have been marginalized by laws that exempt agriculture from many labor
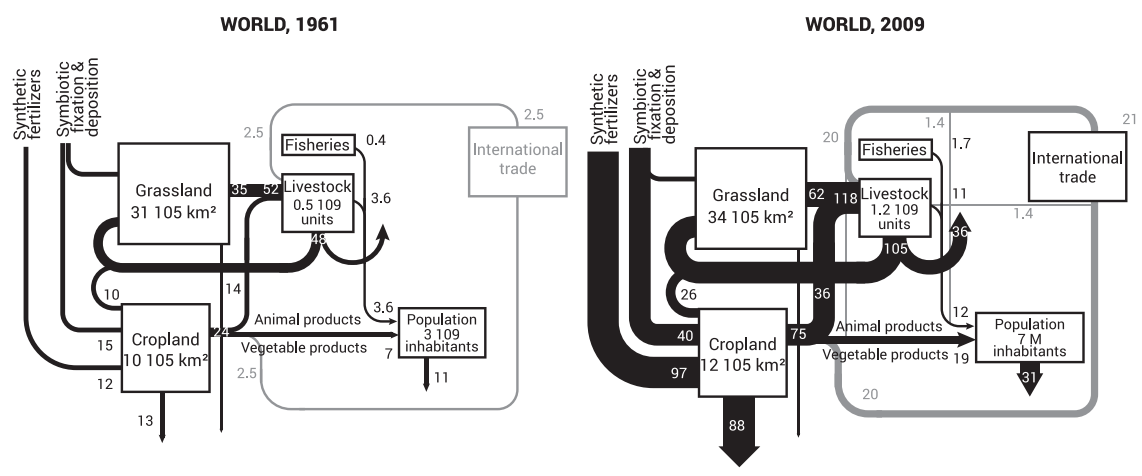

Teragrams Nitrogen $(\mathrm{TgN})$ per year

Figure 13.3 Generalized representation of Nitrogen transfers through the world agrofood system, 1961 and 2009.

Source: TEEB, 2018; adapted from Lassaletta et al. 2016. 
protections and by many policies that make them vulnerable to exploitation (Wilde, 2018). International borders are permeable for people, but the fate of undocumented immigrants who enter North America or Europe in search of work puts them at particular risk; the threat of deportation robs them of what small opportunities they have to organize and collectively bargain.

In the pursuit of the lowest cost of production for globally traded commodities, global food companies tend to source from countries where the cost of labor is least expensive, all other things being equal. The resulting terms of employment of the agricultural workforce, under such conditions, is hardly acceptable, with respect to wages, hours of work, and health and safety. Yet such terms of employment are essentially a "necessary ingredient" of cheap food. A caveat that will need to be addressed, in exploring how measures to introduce TCA might capture the costs of externalities, is that the international nature of the global food system allows burdens to be shifted almost imperceptibly along the food value chain. Within food value chains, assigning costs for negative externalities could fall heavily on farming communities, the agricultural labor force, and low-income consumers. Equally, attributing benefits for positive externalities might rarely accrue to the less powerful actors in food value chains - again, farming communities and the agricultural labor force, unless policy exists to assign equitable allocations. The challenge to do so is even greater with the international trade in foodstuffs and thus the need for international policy development. It is unfortunate, but the reality is that trade rules negotiated internationally strongly lack in negative externalities. WTO trade rules favor the lowest-cost producers and refuse to consider how such costs are reduced. In critical rulings, national or local governments have been prevented from taking measures that internalize external costs or restrict trade when imported goods fail to internalize costs. This feeds a race to the bottom instead of the desired "harmonization upward" of environmental standards and practices (Wise, 2019).

As nation-states position themselves with respect to international markets, all countries must decide what they want to import and what they want to produce domestically. To decide to commit to domestic food production inevitably affects international markets, as does the decision to import affects domestic markets. The application of TCA to food policy could be a helpful way to define these "virtual borders" and to understand what the actual costs and trade-offs are that they are dealing with.

\section{Box 13.1 Beyond GDP: Multidimensional Indicators of Well-Being}

\section{Amanda Jekums}

Gross Domestic Product (GDP) has long been the standard metric for assessing the national economic prosperity and societal progress of countries around the globe. However, its basis in extractive and damaging practices, coupled with increasing rates of pervasive social injustice and income inequality, demonstrates that GDP is an inadequate and inaccurate measure 
of individual living standards and collective well-being. Over the past 25 years, income inequality among Organisation for Economic Co-operation and Development countries has increased seven times over. The average income of the richest $10 \%$ of the population is now nine times that of the poorest $10 \%$ (2019). Clearly the benefits of GDP growth are not reaching everyone.

Given its limitations, countries and citizens around the world are rejecting GDP as the sole measure of success. Similar to the aims of True Cost Accounting to identify metrics that go well beyond single and linear measures of success, the examples provided below illustrate creative examples of how countries are moving beyond GDP towards multidimensional indicators of wellbeing.

In 2008 Bhutan formally adopted a new policy principle to promote conditions that will enable the pursuit of Gross National Happiness (GNH) (Kingdom of Bhutan, 2008). The multidimensional concept of GNH takes a systems approach, which measures nine domains of $\mathrm{GNH}$ : psychological well-being, health, time use, education, cultural diversity and resilience, good governance, community vitality, ecological diversity, resilience, and living standards. The practice allows governments to incorporate this information in decisions on policies and projects and enables targeted responses to specific situations or causes of unhappiness. The process has also encouraged public citizens and private entities alike to think more holistically (Ura et al., 2012).

Vanuatu is a small island country in the southwestern Pacific Ocean. As the world's most at-risk country for natural disasters (Bündnis Entwicklung Hilft, 2019), it is not surprising that their highest level policy framework is composed of indicators directly linked to the United Nations' Sustainable Development Goal. Launched in 2016, the Vanuatu 2030 People's Plan focuses on 15 priority policy objectives: happy and healthy people, an inclusive and equitable society, sustainable land management and food production, conservation and biodiversity, climate resilience, supportive infrastructures, and strong economic and employment opportunities (Department of Strategic Policy, Planning and Aid Coordination, 2017). Collecting data on novel social indicators present a challenge, but progress has been positive, particularly in connecting their national vision for well-being and sustainability to action on the ground in villages and urban centres across the country (Government of The Republic of Vanuatu, 2018).

Most recently, New Zealand introduced its first well-being focused budget in 2019 (New Zealand Treasury, 2019a). The framework measures similar domains as Bhutan's GHN and the Vanuatu 2030 People's Plan, which are categorized under four capitals: financial and physical, human, natural, and social. The data is collected in an online Living Standard Framework (LSF) Dashboard (New Zealand Treasury, 2019b), which informs Ministers on priorities for improving well-being. It is also open to the public in an effort to promote transparency and civic engagement. One of the LSF indicators measures 
trust in government institutions. Recent research has attributed New Zealand's success in eliminating the coronavirus to a high trust in authorities (Wilson, 2020), demonstrating the importance of measuring alternative indicators of societal progress and using the data to improve well-being.

Economic wealth and social well-being are both derived from capital stocksnatural, social, human, and produced-and these capitals must be used and managed in ways that ensure that they maintain their value over time. Single measures of success like GDP (and yield per acre in agriculture, for example) promote growth at all costs, ignoring the diversity of inputs and compounding negative impacts. Despite challenges related to defining appropriate indicators, collecting data, and reporting on these holistic well-being frameworks, they illustrate-in a profoundly hopeful way-the opportunity to move beyond GDP as the dominant economic measure. By focusing more broadly, these enterprising countries are using alternative indicators of success to reveal transformational pathways towards sustainable and equitable societal progress.

\section{Referenced works}

Bündnis Entwicklung Hilft. (2020). The WorldRiskReport. Available at: www. worldriskreport.org

Department of Strategic Policy, Planning and Aid Coordination. (2017). Vanuatu 2030 | The People's Plan: National Sustainable Development Plan 2016-2030 Monitoring and Evaluation Framework. Available at: www.gov.vu/images/publications/NSDP\%20M\&E\%20Framework.pdf.

Government of The Republic of Vanuatu. (2018). Annual Development Report 2018. Available at: www.gov.vu/images/publications/Annual_ Development_Report_2018.pdf.

New Zealand Treasury. (2019a). The Wellbeing Budget. Available at: https:// treasury.govt.nz/sites/default/files/2019-06/b19-wellbeing-budget.pdf.

New Zealand Treasury. (2019b). Measuring Wellbeing: The LSF Dashboard. Available at: https://treasury.govt.nz/information-and-services/nz-econom y/higher-living-standards/measuring-wellbeing-lsf-dashboard.

Organisation for Economic Co-operation and Development. (2019). Inequality. Available at: www.oecd.org/social/inequality.htm.

Kingdom of Bhutan. (2008). The Constitution of The Kingdom of Bhutan. Available at: www.nationalcouncil.bt/assets/uploads/files/Constitution\% 20\%20of\%20Bhutan\%20English.pdf.

Ura, K., Alkire, S., Zangmo, T., \& Wangdi, K. (2012). An Extensive Analysis of GNH Index. Centre for Bhutan Studies. Available at: www.grossnationa Ihappiness.com/wp-content/uploads/2012/10/An\%20Extensive\%20Ana lysis\%20of\%20GNH\%20Index.pdf.

Wilson, S. (2020). Pandemic Leadership: Lessons from New Zealand's Approach to COVID-19. Leadership, 16(3). https://doi.org/10.1177/ 1742715020929151. 


\section{International Entry Points}

Building on the rationales identified above for an international agenda on TCA in food and agriculture, mention has been made in a number of policy venues and documents negotiated and adopted on an international level.

The first of these is the CFS's High Level Panel of Experts report (High Level Panel of Experts on Food Security and Nutrition, 2019), on "Agroecological and other innovative approaches for sustainable agriculture and food systems that enhance food security and nutrition," as adopted by the Steering Committee of the HLPE and presented at the October 2019 meeting of the intergovernmental body. The report, in its summary, made the following points:

It is clear that market forces, left to themselves, are unlikely to result in transitions towards [sustainable food systems] SFSs. This is because there are many externalities associated with production, processing and distribution of food that are not priced and because the power exerted from the increasingly concentrated agri-food input and retail sector often works against addressing these externalities (para 29).

A considerable inertia, manifest in public policies, corporate structures, education systems, consumer habits and investment in research, favors the currently dominant model of agriculture and food systems, representing a series of lock-ins. In the dominant model, environmental and social externalities are not properly considered and, therefore, not appropriately factored into decisions influencing the development of food systems. To overcome this inertia and challenge the status quo.... (para 30).

Key changes in agriculture and food policies that could contribute to transitions towards SFS for FSN include: putting greater emphasis on health and nutritional benefits; implementation of true cost accounting; [inter alia]. (para 32).

In its recommendations the report urged that:

States and IGOs, in collaboration with academic institutions, civil society and the private sector, should: (inter alia) recognize the importance of true cost accounting for negative as well as positive externalities in food systems and take steps to effectively implement it where appropriate; (Recommendation 5)

Secondly, the 194 member nations of the FAO, two associate members, and the European Union adopted a strategy on biodiversity mainstreaming across agricultural sectors in December 2019 (Food and Agriculture Organization of the United Nations, 2020). The logic behind this strategy has been a recognition of the spiraling declines of biodiversity for agricultural reasons, on the one 
hand (Díaz et al., 2020), and of the critical dependence of sustainable agriculture on biodiversity and ecosystem services on the other (Food and Agriculture Organization of the United Nations, 2020). The strategy, as adopted, calls for:

Support provided to Members, at their request, to enhance their capacity to mainstream biodiversity (Outcome 1), [specifically to]

Provide advice on options to internalize the positive and negative economic, environmental and social impacts (externalities) of different agriculture and food systems (Activity 1.10); and

Advocate the recognition of the role of biodiversity for food security and nutrition (Outcome 3), [specifically to]

Raise awareness of stakeholders along the value chain of the positive and negative environmental and social impacts (externalities) of the different agriculture and food systems (Activity 3.2).

Other entry points looming on the horizon are the development of "Systems of Environmental-Economic Accounting (SEEA)"; is a framework for national accounting to go beyond GDP by integrating economic and environmental data (https://seea.un.org), together with other work on developing global TCA standards for the private sector, as described in this volume. The Sustainable Development Goals (www.un.org/sustainabledevelopment/sustaina ble-development-goals/) speak directly to the need to bring a far broader perspective than GDP, along the lines of TCA, into statistics, planning, and development, through at least two targets:

15.9 By 2020, integrate ecosystem and biodiversity values into national and local planning, development processes, poverty reduction strategies and accounts.

17.19 By 2030, build on existing initiatives to develop measurements of progress on sustainable development that complement gross domestic product, and support statistical capacity-building in developing countries.

We are woefully behind on the first target and have much work to do on both. The UN Food Systems Summit (www.un.org/sustainabledevelopment/foodsystems-summit-2021) to be convened by the Secretary-General in autumn 2021 (www.un.org/sustainabledevelopment/food-systems-summit-2021/) is a historic opportunity for food system transformation. However, it would only be able to meet its goal to drive this transformation if it genuinely embraces TCA in food and agriculture.

National governments have many multilateral venues available to explore and develop true cost policies in food and agriculture. Significantly, both the UN Convention on Biological Diversity and the UN Framework Convention on Climate Change (UNFCCC), in recent decisions (such as mainstreaming biodiversity into sectors including agriculture, CBD/COP/DEC/XIII/3; UNFCCC's decision 4/CP.23 on the "Koronivia joint work on agriculture") 
have turned increasingly to focus on the role of food and agriculture in both biodiversity loss and climate change. Their related bodies have issued recent reports and assessments underscoring the dependences and linkages between ecosystem services, biodiversity, climate change adaptation and mitigation and productive lands (Intergovernmental Panel on Climate Change, 2019; Intergovernmental Science-Policy Platform on Biodiversity and Ecosystem Services, 2019). All of these reports seek policies that can stem the tide of ecosystem degradation and build regenerative systems, for which TCA holds great potential as a mechanism to change the dynamic. National commitments under these conventions (National Biodiversity Strategies and Action Plans for the Convention on Biological Diversity and the National Determined Contributions of the UNFCCC) are key areas where national polices can be presented. However, as the Global Biodiversity Outlook 5 has summarized after a ten-year period of implementation of an agreed global goal: "None of the Aichi Biodiversity Targets will be fully met, in turn threatening the achievement of the Sustainable Development Goals and undermining efforts to address climate change." (Global Diversity Outlook 5, 2020, pp. 2). This is the second time that a set of ten-year global biodiversity goals have failed to have been met. The question needs to be addressed as to what lessons can and must be learned from the implementation failure of global targets; simply agreeing on general global targets without a clear implementation strategy and a sound monitoring mechanism will not solve the problem.

True cost policies in food and agriculture-if implemented at the level of companies and national governments and used for the monitoring of the flows of values of the different capitals - have the potential to shed light on progress or failure of implementation of such agreements. This requires the engagement and buy-in of multiple stakeholders through inclusive processes and the development of an agreed system of standard reporting beyond productive capital. TCA should not be seen as another attempt to hide the real costs of our lifestyle- "greenwashing" unsustainable production-but to display all positive and negative externalities of production and consumption. So far, the aforementioned processes have not adopted a rigorous TCA but have continued to work on new global goals. Experience made so far with two decades of global biodiversity goals without an appropriate monitoring and reporting framework provides a clear message: There is no real progress without changing the economic drivers of unsustainable production and consumption.

One of the most respected governance structures is the Committee on World Food Security (CFS), a foremost inclusive, international, and intergovernmental platform. In addition to government representatives, all stakeholders from civil society, academia, and the private sector can channel their inputs and are actively engaged in the discussions. CFS is widely recognized also among the UN organizations and could be followed by national governments (and by the Food Systems Summit) as an inclusive model. The highquality, neutral, science-based CFS HLPE Reports and the CFS "products" (adopted by consensus, after a multi-stakeholder policy convergence process) 
could be excellent tools for governments for the elaboration and design of their integrated, systemic food policies. In particular, negotiations on Voluntary Guidelines on Food Systems and Nutrition and on Agroecology Policy Recommendations are ongoing and highly relevant to TCA in agriculture and food; TCA should be both guiding and driving principles of CFS discussions and Summit preparations as well.

Concrete steps on national governance levels that can realize the reforms needed would include:

- Trade reform that allows environmental and other true-cost considerations to inform and shape trade agreements;

- Elimination of policies that promote forms of agriculture and food production with high negative externalities; and

- Recognition of healthy and nutritious food as a human right, secured through income equity; and

- Based on TCA, elaboration of policy incentives (positive and negative) to orient all stakeholders (including smallholder farmers and private multinationals) to opt for the appropriate decisions

Many key actors in the intergovernmental processes, national governments, and the private sector can promote, incorporate, and respect new investment guidelines that account for positive and negative externalities in Food and Agriculture.

Thus, the door is open on both international and national levels, for advancing on the concept and application of TCA in food and agriculture, reinforced by the work of the UNEP's The Economics of Biodiversity and Ecosystem Services to develop and refine approaches, frameworks and tools for the agrifood sector (http://teebweb.org/agrifood/). Projects are also currently underway to fully integrate TCA in the standard accounts of private sector to ensure that all capitals involved in the food systems can be reported and assessed (https:// tca2f.org/reports/) and (https://futureoffood.org/wp-content/uploads/2020/07/ TCA-Inventory-Report.pdf).

\section{Note}

1 For example, Bayer states that "By the middle of the century, the demand for agricultural products will be 50 percent higher on average than in 2013. An increase of 112 percent is forecast for the Sub-Saharan Africa and South Asia regions" (Bayer, 2017). Available at: www.bayer.com/en/the-future-of-agriculture-and-food.aspx.

\section{References}

Alexandratos, N. \& Bruinsma, J. (2012). World agriculture towards 2030/2050: the 2012 revision. ESA Working paper. Rome: Food and Agriculture Organization of the United Nations. 
Andrieu N. \& Kebede Y. (2020). Climate Change and Agroecology and case study of CCAFS. CCAFS Working Paper no. 313. Wageningen: CGIAR Research Program on Climate Change, Agriculture and Food Security.

Berners-Lee, M., Kennelly, C., Watson, R., \& Hewitt, C.N. (2018). Current global food production is sufficient to meet human nutritional needs in 2050 provided there is radical societal adaptation. Elementa: Science of the Anthropocene, 6(1).

Biovision \& IPES-Food. (2020). Money Flows: What is holding back investment in agroecological research for Africa? Biovision Foundation for Ecological Development \& International Panel of Experts on Sustainable Food Systems.

Cox, C. \& Schechinger, A.W. (2018). America's nitrate habit is costly and dangerous: Prevention is the solution, but voluntary actions fall short. EWG, October 2, 2018. Available at: www.ewg.org/research/nitratecost.

Dalin, C., Konar, M., Hanasaki, N., Rinaldo, A., \& Rodriguez-Iturbe, I. (2012). Evolution of the global virtual water trade network. Proceedings of the National Academy of Sciences, 109(16), 5989-5994. doi:10.1073/pnas.1203176109.

Díaz, S., Settele, J., Brondízio, E., Ngo, H., Guèze, M., Agard, J., ... \& Chan, K. (2020). Summary for policymakers of the global assessment report on biodiversity and ecosystem services of the Intergovernmental Science-Policy Platform on Biodiversity and Ecosystem Services.

Fakhri, M. \& Tzouvala, N. (2020). To reduce hunger governments need to think beyond making food cheap. The Conversation, July 17. Available at: https://theconversation. $\mathrm{com} /$ to-reduce-world-hunger-governments-need-to-think-beyond-making-foodcheap-142361.

Food and Agriculture Organization of the United Nations. (2009). How to Feed the World in 2050. In Executive Summary-Proceedings of the Expert Meeting on How to Feed the World in 2050. Rome: Food and Agriculture Organization of the United Nations.

Food and Agriculture Organization of the United Nations. (2014). The state of food and agriculture 2014: Innovation in family farming. Rome: Food and Agriculture Organization of the United Nations.

Food and Agriculture Organization of the United Nations. (2019). The State of the World's Biodiversity for Food and Agriculture. Food and Agriculture Organization Commission on Genetic Resources for Food and Agriculture Assessments, Rome.

Food and Agriculture Organization of the United Nations. (2020). FAO Strategy on Mainstreaming Biodiversity across Agricultural Sectors. Rome: Food and Agriculture Organization of the United Nations. doi:10.4060/ca7722en.

Food and Agriculture Organization of the United Nations, International Fund for Agricultural Development, UNICEF, World Food Programme \& World Health Organization. (2020). The State of Food Security and Nutrition in the World 2019. Safeguarding against economic slowdowns and downturns. Rome: Food and Agriculture Organization of the United Nations.

Global Diversity Outlook 5. (2020). Global Biodiversity Outlook 5-Summary for Policy Makers. Montréal, QC: Secretariat of the Convention on Biological Diversity.

High Level Panel of Experts on Food Security and Nutrition. (2014). Food losses and waste in the context of sustainable food systems. A report by the High Level Panel of Experts on Food Security and Nutrition of the Committee on World Food Security, Rome. Available at: www.fao.org/3/a-i3901e.pdf.

High Level Panel of Experts on Food Security and Nutrition. (2017). Nutrition and food systems. A report by the High Level Panel of Experts on Food Security and Nutrition of the Committee on World Food Security. Rome. (No. 8). CFS Committee on World Food Security HLPE. Available at: www.fao.org/3/a-i7846e.pdf. 
High Level Panel of Experts on Food Security and Nutrition. (2019). Agroecological and other innovative approaches for sustainable agriculture and food systems that enhance food security and nutrition. A report by the High Level Panel of Experts on Food Security and Nutrition of the Committee on World Food Security. Rome. (No. 14). CFS Committee on World Food Security HLPE. Available at: www.fao. org/3/ca5602en/ca5602en.pdf.

Intergovernmental Science-Policy Platform on Biodiversity and Ecosystem Services. (2019). Global assessment report on biodiversity and ecosystem services of the Intergovernmental Science-Policy Platform on Biodiversity and Ecosystem Services. Bonn: IPBES Secretariat.

Intergovernmental Panel on Climate Change. (2019). Chapter 4: Land degradation. In: Special Report on Climate Change and Land.

Lassaletta, L., Billen, G., Garnier, J., Bouwman, L., Velazquez, E., Mueller, N.D., \& Gerber J.S. (2016). Nitrogen use in the global food system: past trends and future trajectories of agronomic performance, pollution, trade, and dietary demand. Environmental Research Letters, 11(9), 095007.

Organisation for Economic Co-operation and Development. (2019). Biodiversity: Finance and the Economic and Business Case for Action. Report prepared for the G7 Environment Ministers' Meeting, 5-6 May 2019. Organisation for Economic Cooperation and Development. Available at: www.oecd.org/environment/resources/ biodiversity/Executive-Summary-and-Synthesis-Biodiversity-Finance-and-the-Economicand-Business-Case-for-Action.pdf.

Pengue, W., Gemmill-Herren, B., Balázs, B., Ortega, E., Viglizzo, E., Acevedo, F., Diaz, D. N., Díaz de Astarloa, D., Fernandez, R., Garibaldi, L.A., Giampetro, M., Goldberg, A., Khosla, A., \& Westhoek, H. (2018). 'Eco-agri-food systems': today's realities and tomorrow's challenges. In TEEB for Agriculture \& Food: Scientific and Economic Foundations (pp. 57-109). Geneva: UN Environment.

Pimbert, M. \& Moeller, N. (2018). Absent agroecology aid: on UK agricultural development assistance since 2010. Sustainability, 10(2): 505. doi:10.3390/su10020505.

Ribaudo, M., Delgado, J., Hansen, L., Livingston, M., Mosheim, R., \& Williamson, J. (2011). Nitrogen in agricultural systems: Implications for conservation policy. USDAERS Economic Research Report, 127.

Sen, A. (1981). Poverty and famines: an essay on entitlement and deprivation. Oxford: Oxford University Press.

Smith, L. C. \& Haddad, L. (2015). Reducing child undernutrition: past drivers and priorities for the post-MDG era. World Development, 68, 180-204.

The Economics of Biodiversity and Ecosystem Services. (2018). TEEB for Agriculture \& Food: Scientifc and Economic Foundations. Geneva: UN Environment.

The Economist. (2020). The global food supply chain is passing a severe test; keeping the world fed, May 9, 2020.

Townsend, R. A. \& Howarth, R. (2010). Fixing the Global Nitrogen Problem. Scientific American, 302(2), 64-71.

United Nations Environment Programme. (2015). International Trade in Resources: A Biophysical Assessment, Report of the International Resource Panel, United Nations Environment Programme

United Nations Environment Programme. (2016). Food Systems and Natural Resources. A Report of the Working Group on Food Systems of the International Resource Panel (pp. 1210-1226).Wilde, P. (2018). Food Policy in the United States: An Introduction. Abingdon: Routledge. 


\section{Gemmill-Herren, Kálmán \& Müller}

Wise, T.A. (2013). Can we feed the world in 2050? A scoping paper to assess the evidence. Global Development and Environment Institute Working Paper No. 13-04. Medford, MA: Tufts University.

Wise, T.A. (2019). Eating Tomorrow: Agribusiness, Family Farmers, and the Battle for the Future of Food. New York, NY: The New Press.

Wise, T.A. (2020). Failing Africa's Farmers: An Impact Assessment of the Alliance for a Green Revolution in Africa. Medford, MA: Tufts University. Available at: https://sites.tufts. edu/gdae/files/2020/10/20-01_Wise_FailureToYield.pdf. 